\title{
THE FUNCTIONAL OVERLAP OF ENFORCEMENT AND IMPLEMENTATION TOOLS
}

\begin{abstract}
Stine Andersen*
Summary: This article argues that notwithstanding the doctrinal distinction between enforcement and implementing measures, there are effective points of functional overlap between enforcement powers and certain types of implementing tools, which are lawful in that they serve other aims and purposes than enforcement. Since the Commission employs these measures in conjunction with the general infringement procedure or as an alternative with the less discernible aim of ensuring compliance, a comprehensive EC enforcement analysis must take note of them. Potential legal constraints on the Commission in employing these instruments, such as the proportionality principle, are among the questions raised. In addition, the article explores how any perceived misuse may have ramifications for the Commission's ability to have future implementation powers established in secondary law.
\end{abstract}

\section{Introduction}

This article argues that in parallel to the Commission's formal means of monitoring Member States' compliance with EC law under Article 226 $\mathrm{EC}$, there are various 'implementation measures' that can be employed to achieve the same objectives and thus supplement or compensate the Commission for its absence of sharper secondary enforcement powers. ${ }^{1} \mathrm{~A}$ number of examples of such functional overlap between enforcement and implementation measures will be examined in order to determine to what extent the implementation measures can serve as effective substitutes/ complements to enforcement mechanisms. When evaluating the increasing reliance on implementation measures as a tool to ensure Member State compliance with Community law, it should be kept in mind that the

\footnotetext{
* Stine Andersen, PhD, European University Institute; Visiting Research Fellow, Cambridge University. I wish to thank Gráinne de Búrca, Christian Joerges, Joanne Scott, the anonymous reviewers and the participants at the Jean Monnet Seminar 'Advanced Issues of European Law - European Law after the Big Bang Enlargement: Assessment and Perspectives' (Dubrovnik, 29 April - 6 May 2007) for their very helpful comments and suggestions on earlier drafts of this article. The usual disclaimer applies. stine.andersen@eui.eu

1 For an analysis of some of the tools also considered in this article, see Alberto $\mathrm{J}$ Gil Ibáñez, 'Commission Tools for the Supervision and Enforcement of EC Law Other Than Article 169 EC Treaty - An Attempt at Systematization' (1998) Jean Monnet WP 12 and Alberto J Gil Ibáñez, 'Exceptions to Article 226: Alternative Administrative Procedures and the Pursuit of Member States' (2000) 6 EJL 148.
} 
EC Treaty does not provide a legal basis for the Council to establish ad hoc enforcement procedures in secondary legislation. ${ }^{2}$ Besides a few exceptions, notably in relation to Member State budgetary discipline where the general infringement procedure is suspended, the Council does not normally possess enforcement powers under the first pillar. Furthermore, the European Court of Justice (hereinafter the ECJ or the Court) has construed a narrow scope for implied powers. Thus, it would be difficult and indeed unlawful to have decision-making mechanisms coexist with the enforcement powers of the Commission and ECJ respectively, if they were to imply an authoritative interpretation of Community law or empower the Commission to make a binding assessment of Member State behaviour and its conformity with Community law. The Council's lack of general enforcement powers in turn precludes it from delegating any such authority to the Commission. Thus, Article $7 \mathrm{EC}$ and the principle of attributed powers mark an important limitation on the legislator and its ability to legitimately confer enforcement powers upon the Commission. The Member States clearly do not want a general or ad hoc reinforcement of the Commission's enforcement powers, which would not only change the relationship between the Commission and individual non-compliant states, but also shift the institutional balance of power within the Community.

The distinction between implementation and enforcement merits brief clarification. The EC Treaty represents a catalogue of primary norms, encompassing the internal and external competences of the regime as well as the powers of the legislative, adjudicative and executive branches of government. Within this framework of primary law, the legislator is empowered to articulate substantive rules - secondary law. In addition, there are organisational, as well secondary, rules that establish the specifications required for putting the law into practice. Such secondary and tertiary, implementing, norms facilitate the "putting into effect of legislation, decisions, or policies formulated and agreed by the EU's policy-making institutions'. ${ }^{3}$ Secondary and tertiary norms are plentiful within the Community and unprecedented in any other international law-regime. Enforcement, in contrast, denotes the act of compelling compliance with a legal obligation and only becomes relevant in the phase succeeding implementation when the question arises whether a given law has been implemented and enforced effectively. According to Article

2 Stine Andersen, 'The European Commission's Quest for Strengthened Powers of Enforcement -Procedural and Substantive Appraisal of Selected Legislative Proposals', paper presented at the 4 th Convention of the Central and East European International Studies Association (University of Tartu, Estonia, 25-27 June 2006) <http://www.ceeisaconf.ut.ee/ orb.aw/class=file/action=preview/id=164087/andersen.pdf $>$ accessed 21 September 2007

3 M Cini, 'Implementation' in Michelle Cini (ed), European Union Politics (Oxford University Press, Oxford 2003) 349. 
211 EC, the Commission shall supervise Member State compliance with Community law. The tools available to it in doing so are stipulated in Articles 226 and 228 EC - the general Treaty infringement procedure. Article 226 EC, addressing Member State failure to observe Community law, consists of a two-stage administrative phase and a judicial phase. During those phases the Commission has absolute discretion in deciding whether to pursue an infringement and ultimately to refer it to the ECJ. The ECJ possesses sole authority to undertake interpretation of Community law and appraise Member State conduct ${ }^{4}$ and its judgments are declaratory. Article 228 EC concerns failure to comply with a judgment of the Court. The procedure is largely similar to Article 226 EC however the Commission can request the Court to impose a lump sum or/and a penalty payment on the defaulting Member State.

In the framework outlined above, the notions of enforcement and implementation are distinct and appear to be neither compatible nor interchangeable. However, there are cases in which, the Commission rather than making use of its implementation powers could have pursued a situation as an infringement case under Article 226 EC. As will be explained in more detail in section III, the Common Fisheries Policy (CFP) provides an example of a policy area in which, the Commission enjoys non-enforcement measures that can effectively be employed in combination with the Commission's tools of enforcement. To illustrate, it may invoke emergency measures such as establishing a fishing moratorium to forestall imminent risks of fish-stock deterioration. The measure is not aimed at ensuring compliance and is not an enforcement tools per se. However when the formal conditions for taking such action are present, the Commission can employ them against a Member State in breach of the Treaty and thus utilise the emergency measures in isolation or together with the general infringement procedure. In the latter case, the mere threat of emergency measures can function as a bargaining tool in the administrative phase of Article 226 EC. In addition, when emergency measures are invoked, they effectively bring a perceived infraction to standstill while infringement proceedings are pending. Other types of implementation mechanisms established in secondary law are explicitly intended as tools to prevent infringements. The Member States' obligation to notify the Commission about draft technical regulations and the Commission's corresponding powers to take action are examples thereof.

The argument proceeds as follows. First, the notion of implementation within the EC Treaty will be discussed in some detail. Selected measures will be grouped and examined under the headings (i) preventive

4 Article 220 EC. 
measures (ii) safeguard and emergency measures and (iii) conditionality. ${ }^{5}$ The closing section concerns issues regarding the application of implementation measures with the aim of securing Member State compliance. Potential legal constraints on the Commission in employing these, such as the proportionality principle, are among the questions raised. It is argued that although the Commission is largely at liberty to employ these measures with a functional aim of ensuring compliance, any perceived misuse may have ramifications on the Commission's ability to obtain implementation powers when subsequent secondary laws are established. At least the Council will be likely to establish Member State oversight mechanisms in connection with the delegation of power.

\section{The scope of implementation}

Powers to implement Community law rest at the level of the state and as well as at the Community level without any definite logic of separation. Similarly, there is no automatic relationship with the type of competence in question. ${ }^{6}$ The Convention working group on the delimitation of competences between the European Union and the Member States however maintains that as a general rule "competence to implement and apply legislation in accordance with their respective constitutional rules [...] rests with the Member States [...] The Community exercises such competence in a subsidiary capacity only'. ${ }^{7}$ The interpretation is based on a combined reading of Articles 10, 202 and 211 EC.

To the extent that implementation takes place at the supranational level, it follows from Article 202, that the Council shall delegate powers of implementation to the Commission. It may however reserve the right to exercise implementing powers in specific cases. Notwithstanding the wording of Article 202 EC that clearly suggests an obligation to delegate, the Council effectively has an absolute power to reserve the right of implementation. That is to say, a Council decision to reserve the powers to implement in a specific case will not be examined in substance by the ECJ. However, when quantifying the Community's main source of tertiary binding law, the Commission far outweighs the Council in sheer volume. ${ }^{8}$ Thus delegation is not just the rule in legal terms, but also in actual terms. In reserving powers to implement, the Council shall

\footnotetext{
5 This enumeration of directives and regulations is not exhaustive.

6 European Convention, 'Delimitation of competence between the European Union and the Member States - Existing system, problems and avenues to be explored' (Note) CONV 47/02, 15 May 2002.

7 Ibid.

8 G Haibach, 'Separation and Delegation of Legislative Powers: A Comparative Analysis' in Mads Andenas and Alexander Türk (eds), Delegated Legislation and the Role of Committees in the EC (Kluwer Law International, The Hague 2000).
} 
demonstrate in depth the grounds for its choice ${ }^{9}$ and explain its reasons for departing from the conventional procedure. ${ }^{10}$ Therefore, with the exception of instances where the Commission is explicitly empowered by the EC Treaty, there has to be express delegation from the Council. The Commission's corresponding institutional powers to carry out implementation are stipulated in Article 211 EC: 'The authorising norm [...], the delegating norm [...] and the norm exercising powers contained in the enabling norm (implementing act) form a whole that contains the relevant law'. ${ }^{11}$ Derived legal norms must be within the substantive scope of their enabling provision because the institutions cannot act beyond their explicitly granted powers. This follows from the principle of attributed powers as well as from the wording of Article $249 \mathrm{EC}$, which denotes a range of instruments available to the institutions 'in order to carry out their task and in accordance with the provisions of this Treaty'. Jürgen Bast notes that the wording articulates 'a strict hierarchy between (primary) Treaty law and (secondary) derived law' and, he continues, this hierarchy of norms is indeed a 'precondition that makes the principle of attributed powers work'. ${ }^{12}$

Employing a contextual and essentially pragmatic understanding of Article $211 \mathrm{EC}$, the ECJ has consistently held that the scope for implementation is to be interpreted in a fairly broad manner. ${ }^{13}$ On condition that it does not lay down measures which conflict with the delegating act, the Commission may thus 'adopt all the measures which are necessary or appropriate for the implementation of the basic legislation'. ${ }^{14}$ Whereas Articles 202 and 211 EC simply use the expression implementation without specification, it is clear from jurisprudence that the notion of delegated implementation powers encompasses both powers 'to

9 Case C-16/88 Commission v Council [1989] ECR 3457 para 10.

10 Case C-257/01 Commission v Council [2005] ECR I-345 para 51.

11 GF Schäfer, Georg Haibach and Alexander Türk, 'Subproject 3: Policy Implementation and Comitology Committees' (May 2000) EIPA WP 39:4, 47 <http://www.eipa.nl/Publications/Summaries/2000/chap_4.pdf> accessed on 3 October 2007.

12 Jürgen Bast, 'On the Grammar of EU Law: Legal Instruments' (2003) Jean Monnet WP 9 p 17.

13 Joined Cases C-37/02 and C-38/02 Di Lenardo Adriano Srl/Dilexport Srl v Ministero del Commercio con l'Estero (reference for preliminary ruling) [2004] ECR I-6911 para 53. The judgment in Case C-240/90 Germany $v$ Commission [1992] ECR I-5383 para 36 states that Articles 202 and $211 \mathrm{EC}$ 'distinguish between rules which, since they are essential to the subject-matter envisaged, must be reserved to the Council's power, and those which being merely of an implementing nature may be delegated to the Commission'. The classification 'essential' is reserved for provisions intended to give concrete shape to the fundamental guidelines of Community policy. See para 37 of this same judgment.

14 Joined Cases C-9/95, C-23/95 and C-156/95 Belgium and Germany $v$ Commission [1997] ECR I-645 para 37. 
adopt generally applicable or individual measures within specific areas'. ${ }^{15}$ The Treaty itself does not make a distinction between these two types of power. It is precisely the lack of restrictions attached to the notion of implementation in the Treaty which led the Court to reject a narrow reading of its scope. Implementation can thus be thought of as covering both (i) legislative powers and (ii) executive powers. Delegation of legislation is a normative power that enables the Commission to establish general rules or procedures, for applying the rules laid down by the legislator. ${ }^{16}$ The Commission emphasises the merits of delegating legislative powers from the Council to the Commission, particularly in "policy sectors with rapid technical changes'. ${ }^{17}$ These rules are, as are Advocate General Darmon notes, 'of a general and impersonal nature'. ${ }^{18}$ Executive powers enable the Commission to put Community law into operation either through the adoption of detailed provisions or individual decisions. The same Advocate General denotes the latter as administrative implementation. ${ }^{19}$

In considering scope and effect, executive decision-making has manifest similarities with court rulings and such powers appear reminiscent of genuine enforcement tools because they enable the Commission to make concrete decisions. However, as will be demonstrated in the following section, legislative powers can likewise have areas of functional overlap with enforcement measures, in particular when applied with the intention of achieving interpretive clarification of ambiguous legal obligations.

\section{Selected implementation powers}

\section{Preventive measures}

\section{A. Services in the Internal Market}

There are a number of different types of Commission instruments established in secondary legislation with purpose of anticipating noncompliance. In 2004, the Commission tabled a proposal for a framework directive on services in the Internal Market. The proposal contained a 'general legal framework applicable, subject to certain exceptions, to all

15 Case C-16/88 Commission v Council [1989] ECR-3457 para 16 and, in particular, para 11.

16 Case C-298/89 Government of Gibraltar v Council [1993] ECR I-3605.

17 EC Commission, 'Questions and Answers: An Institutional Architecture for the European Union (Peace, Freedom, Solidarity)' MEMO (2002) 285, 5 December 2002.

18 Opinion of Advocate General Darmon in Case C-16/88 Commission v Council [1989] ECR II-3457 para 15.

19 Ibid. 
economic activities involving services'. ${ }^{20}$ This horizontal method was motivated by the perception that infringements within the Internal Market in services are frequently 'common to a large number of different activities and have many features in common'. ${ }^{21}$ In the pre-legislative and legislative period concerning the Commission's proposal, the Commission as well as the European Parliament (hereinafter the EP) raised the issue of non-compliance. The EP stressed the need for 'a rigorous infringement policy vis-à-vis Member States which take measures incompatible with Articles 43 [right of establishment] and 49 [free movement of services] of the Treaty'. ${ }^{22}$ The Commission, for its part, emphasised that obstacles to these provisions do persist and that it would be 'ineffective' and 'unmanageable' to address them individually under the general infringement procedure. ${ }^{23}$ Section three of the Commission proposal lists Member State requirements that are either prohibited or subject to evaluation. Article 14 concerns Member State requirements to be abolished. To illustrate the degree of detail, Article 14(3) contains a prohibition of

restrictions on the freedom of a provider to choose between a principal or a secondary establishment, in particular an obligation on the provider to have his principal establishment in their territory, or restrictions on the freedom to choose between establishment in the form of an agency, branch or subsidiary.

Article 15 requires Member States to examine whether specified domestic requirements are in conformity with conditions of non-discrimination, necessity and proportionality. After drawing up a self-assessment, all Member States derive a mutual evaluation report and declare if planning to maintain any requirements as well as their reasons therefore, in addition to requirements that have been suspended or amended. The procedure thus leaves room for peer review while also facilitating the exchange of arguments based upon interpretation, legal principles and precedent. The Member States can only introduce new requirements if they comply with the conditions of non-discrimination, necessity and proportionality mentioned above. As an additional requirement, any such domestic obligation shall result from new circumstances. ${ }^{24}$ Then,

\footnotetext{
20 EC Commission, 'Proposal for a Directive of the European Parliament and of the Council on services in the internal market' COM (2004) 2 final/3, preamble 3a).

${ }^{21}$ Ibid, preambular point 3a).

22 European Parliament, 'Resolution on the Commission Communication "An Internal Market Strategy for Services"' (4 October 2001) A5-310/2001.

23 EC Commission, 'Proposal for a Directive of the European Parliament and of the Council on the recognition of professional qualifications' COM (2004) 02, para 30.

24 EC Commission (n 20) art 15(5).
} 
[w]ithin a period of 3 months from the date of notification, the Commission shall examine the compatibility of any new requirements with Community law and, as the case may be, shall adopt a decision requesting the Member State in question to refrain from adopting them or to abolish them. ${ }^{25}$

Whereas decisions are binding in their entirety upon those to whom they are addressed, the Commission is merely empowered to request the Member State to refrain from or abolish a requirement. The wording avoids the constraints set by the EC Treaty against ad hoc infringement procedures while ascertaining and formalising a Commission soft-law tool to address potential or existing infringements. Finally, Article 16 specifies a list of prohibited restrictions.

In the preamble of the proposal, the Commission explains that the requirements enumerated in the directive and Article $226 \mathrm{EC}$ have different aims:

While the latter concern individual cases resulting from specific circumstances and measures in a particular Member State, the former are on the other hand aimed at ensuring, in a general and systematic fashion, that the legal systems correspond to the requirements of a genuine internal market in services in which, the freedom of establishment and free movement of services are facilitated. ${ }^{26}$

The proposal for a directive concerning services contains a mechanism that can deal with potential infringements of Community law by systematising Commission scrutiny as well as enabling self-assessment and multilateral peer review of clearly spelled out obligations. Although the procedure attributes a central function to the Commission, it is fairly decentralised in the way it functions. In comparison with the general infringement procedure, this Internal Market procedure displays apparent gains in terms of economies-of-scale, both when measured up to informally negotiated agreements reached during the administrative stage, and to rulings by the Court which merely remedy specific infringement incidents. ${ }^{27}$ The approach seems apt for other policy areas where a substantial body of jurisprudence indicates that there are clusters of compli-

25 EC Commission (n 20) art 15(6). The proposal was adopted as Directive 2006/123/EC of the European Parliament and of the Council of 12 December 2006 on services in the internal market [2006] OJ L376/36. The provision is now Article 15(7); however, no substantive amendments have been made.

26 EC Commission (n 20) 7f), preamble.

27 However, in this course of action there will typically be more states involved and in the judicial phase all Member States and Community institutions may intervene and submit statements of case and of law. See Art 40 of the Protocol on the Statute of the Court of Justice [2001] OJ C80. 
ance failures applying to a large number of Member States. In addition, the Member State interest in ensuring compliance should prevail over any interest in room for manoeuvre in the implementation phase.

\section{B. Draft Technical Regulations}

Standardisation makes up an instrument against barriers to free movement of goods and services and has been hailed as a central measure for the realisation of the Single Market since the first Council Resolution from $1985 .{ }^{28}$ Currently, EC standardisation is largely regulated by Directive $98 / 34^{29}$ and a number of sector specific regulations. Harmonisation of technical standards and regulations are frequently accompanied by preventive clauses. Council Directive 83/189/EEC of 28 March 1983 laying down a procedure for the provision of information in the field of technical standards and regulations is illustrative of this. ${ }^{30}$ In its Communication from 1993 on the handling of urgent situations in the context of implementation of Community rules, the Commission discusses the notion of technical harmonisation measures and its institutional powers: ${ }^{31}$

[T]he Commission must ensure that the directive has been properly implemented [...] It acts under the competences conferred on it by Article 155 [now 211]. Safeguard clauses give the Commission powers of enquiry; these are, however, limited since they are not powers of investigation but involve consultation of the interested parties. [...] Once consultations are completed, the Commission must draw up a report as to whether the measure is justified.

\footnotetext{
28 Council Resolution of 7 May 1985 on a new approach to technical harmonisation and standards [1985] OJ C136/1 and Council Resolution of 28 October 1999 on the role of standardisation in Europe [2000] OJ C141/5.

29 Directive 98/34 of the European Parliament and of the Council laying down a procedure for the provision of information in the fields of technical standards and regulations and of rules on information services [1998] OJ L204/37, amended by Directive 98/48 of the European Parliament and of the Council [1998] OJ L217 art 8 and 9. Directive 98/34/EC now applies to all industrial, agricultural and fishery products as well as Information Society services. EC Commission, 'The Operation of Directive 98/34/EC from 2002-2005' (Commission Staff Working Document) COM (2007) 125 final.

30 Council Directive 83/189/EEC of 28 March 1983 laying down a procedure for the provision of information in the field of technical standards and regulations [1983] OJ L109/8, as amended by Directive 88/182/EC [1988] OJ L81/75, Directive 94/10/EC [1994] OJ L100/30 and Directive 98/34/EC [1998] OJ L204/37. For a comprehensive analysis of Directive 83/189 and subsequent directives on compulsory notification of draft technical regulations, see Stephen Weatherill, 'Compulsory Notification of Draft Technical Regulations: The Contribution of Directive 83/189 to the Management of the Internal Market' (1996) 16 YEL 129.

31 EC Commission, 'Communication on the handling of urgent situations in the context of implementation of Community rules - Follow-up to the Sutherland report' COM (1993) 430, $40 \mathrm{ff}$.
} 
According to the original Council Directive 83/189/EEC, the Member States are obliged to announce to the Commission draft technical regulations and submit a justification for their introduction. The Commission informs the other Member States and can further refer the draft to a Committee for its opinion. The Member States and the Commission are given the chance to make remarks and the Member State must take these into account in the subsequent preparation of the technical regulation. Upon Member State or Commission requests, the final text must be provided to the supplicant. The Member States shall suspend the draft for six months from the date of the notification if the Commission or another Member State presents a comprehensive opinion within three months of that date. The Commission may decide to propose or adopt a directive in response to the notification. In that case, the standstill period is prolonged to 12 months. ${ }^{32}$ The Directive enables the Commission to forewarn a Member State of cases 'where draft technical regulations, if adopted, would run counter to Community law'33 and, the Commission contends, enables the other Member States 'to play an important role in preventing the creation of new technical barriers to trade'. ${ }^{34}$ The mechanism constitutes a key instrument in ensuring the proper functioning of the Internal Market by making it possible for the Commission to 'to identify possible barriers to trade before they enter into force and thus to avoid the need to initiate many infringement procedures'. ${ }^{35}$

The obligation to notify the Commission of draft technical regulations is however no guarantee of compliance and demands monitoring in itself. Thus the Commission initiated procedures under Article 226 EC more than hundred times during the period between 1995 and 1998 in cases where the Member States had failed to notify draft measures or to adopt them before the end of the standstill period. ${ }^{36}$ In a judgment from 1996, the Court ruled on Articles 8 and 9 of Directive 83/189/EEC, ${ }^{37}$ now Directive $98 / 34 / \mathrm{EC},{ }^{38}$ stating that individuals may rely on them before national courts and, notably, that the national courts shall refuse to apply a national technical regulation unless it has been notified in line

32 Council Directive 83/189/EEC (n 30) art 8 and 9.

33 Ibid.

34 EC Commission, 'Communication concerning the non-respect of certain provisions of Council Directive 83/189/EEC of 28 March 1983 laying down a procedure for the provision of information in the field of technical standards and regulations' [1986] OJ C245/4.

35 EC Commission, 'Better monitoring of the application of Community law' (Communication) COM (2002) 725.

36 EC Commission, 'The operation of Directive 98/34/EC from 1995 to 1998' (Report to the Council, the European Parliament and the Economic and Social Committee) COM (2000) 429 .

37 Council Directive 83/189/EEC (n 30) 8-12.

38 Directive 98/34/EC (n 30) 37-48. 
with the directive. Accordingly, breach of the obligation to notify renders the technical regulations concerned inapplicable and consequently unenforceable against individuals. ${ }^{39}$ The legal justification for this is based on the obligation to inform the Commission about draft legislation. The obligation is, the Court ascertains, unconditional and sufficiently precise in terms of content as to establish direct effect. Under Article 226 EC the Commission's acts or forbearance are without any legal significance to legal and private persons. ${ }^{40}$ Thus, in comparison with the general infringement procedure, this type of preventive measure is relatively more effective because of the far-reaching consequences of not complying with the procedure.

\section{Public Procurement/Pre-contractual Review}

In recognition of the time deficiencies of the general infringement procedure and the procedure's inadequacy as a guarantee of compliance, Directive 89/665/EEC on the application of review procedures to the award of public supply and public works contracts, established a notification procedure according to which the Commission can notify a Member State if it considers a contract to be unlawful. In its original proposal for a directive, the Commission proposed a provision according to which the Member States would be obliged to allow the Commission to intervene in the domestic administrative or judicial procedures concerning public procurement. ${ }^{41}$ The procedure, anticipated to strengthen enforcement by private litigants with a view to 'ensur[ing] the precedence of Community public interest and compliance with the Community rules applicable to the award of public supply and public works contracts', was not ultimately adopted. Instead, the ensuing procedure for the award of public contracts authorises the Commission to take interim measures aimed at suspending the implementation of unlawful decisions when it considers that a 'clear and manifest infringement has been committed during a contract award procedure'. ${ }^{42}$ The decision must be taken prior to a contract being concluded. The Commission notifies the Member State explaining its conclusion and the Member State must reply within 21 days of receipt of notification, confirming that the infringement has been

39 Case C-194/94 CIA Security International [1996] ECR I-2201 para 54 and summary.

40 See generally Alberto J Gil Ibáñez (n 1).

41 EC Commission, 'Proposal for a Council Directive coordinating the laws, regulations and administrative provisions relating to the application of Community rules on procedures for the award of public supply and public works contracts' COM (1987) 134 SYN 89.

42 Council Directive 89/665/EEC of 21 December 1989 on the coordination of the laws, regulations and administrative provisions relating to the application of review procedures to the award of public supply and public works contracts [1989] OJ L395/33 preambular para 9. 
corrected or issue a reasoned submission as to why no correction has been made. As a last option, the Member State may issue a notice to the effect that the contract award procedure has been suspended. If a Member State opts for the second scenario because judicial review is already taking place, it must keep the Commission informed of the result thereof when possible. The aim of ensuring enforcement is indisputable. Thus the Council explicitly motivates its act by stating that

the existing arrangements at both national and Community levels for ensuring their [Community Directives on public procurement] application are not always adequate to ensure compliance with the relevant Community provisions particularly at a stage when infringements can be corrected. ${ }^{43}$

At first the measure appears to be a broadening of the Commission's general enforcement powers. However, the procedure is a preliminary measure and should be seen in isolation of the general infringement procedure in spite of its functional aim of ensuring compliance by institutionalising effective and rapid remedies in the case of infringements. The ECJ has clarified the relationship between the procurement procedure and preventive measures in relation to the general infringement procedure. It emphasised that discretionary power to bring an action before the Court remains the exclusive Commission tool against committed infringements when it considers that a Member State has failed to fulfil one of its Community obligations. The special procurement is 'a preliminary measure which can neither derogate from nor replace the powers of the Commission under Article 169 [226 EC]'. ${ }^{44}$ Hence, the Court further notes, the general power to bring a Member State before the Court is unfettered. ${ }^{45}$

In the White Paper on the Internal Market from 1985, the Commission listed preventive measures as one of the ways it intended to "carry out its duties of enforcing the rules' and it continues to acclaim the instruments' merits in the broader context of ensuring compliance. ${ }^{46}$ Preventive measures no doubt constitute a strong Commission tool per se and in conjunction with general enforcement powers should be taken into account when making a comprehensive depiction of the EC enforcement picture. It should at the same time be noted that corrective measures are no longer applied. According to the Commission this is due to the fact

43 Ibid.

44 Case C-359/93 Commission v Netherlands [1995] ECR I-157 para 13.

45 Ibid.

46 EC Commission, 'Completing the Internal Market' (White Paper) COM (1985) 310; 'Internal Market: Commission Presents Ten-Point Plan for Making Europe Better Off IP (2003) 645, 7 May 2003; 'European Governance’ (White Paper) COM (2001) 428, OJ C287. 
that they 'suffer[ed] from several weaknesses (for instance the need for the Commission to make its decision before the contract is signed; and to show that the alleged infringement was "clear and manifest")'. ${ }^{47}$

There is now a range of sector-specific procurement procedures including one on entities operating in the water, energy, transport and telecommunications sectors. ${ }^{48}$ Measures to anticipate compliance such as consultation, notification and also prior consent are exceptionally invasive. Thus, FL Kirgis remarks with reference to international law, 'to the extent that formal procedural structures for prior consultation may be desirable, they should be tailored to recurring, relatively well-defined, troublesome situations'. ${ }^{49}$ Clearly, the EC Council members have not been willing to delegate strong powers to make corrective measures unconditionally. Thus they tie them in to certain Member State safeguards such as the condition that the Commission shall demonstrate that an infringement is clear and manifest. However by doing so these instruments become cumbersome to utilise although they were intended to make up more easily and directly employable complements to the general Treaty infringement procedure. The Commission is of the view that precontractual reviews can be made more effective and it recently issued a proposal for a directive in which the main components aimed at ensuring respect for the right to effective remedy and to a fair trial for private and legal persons. ${ }^{50}$ Given the administrative resources of the Commission, it has been unable to achieve comprehensive supervision of all contracts granted in the Member States under the public procurement Directives, ${ }^{51}$

\footnotetext{
47 EC Commission, 'Impact Assessment Report: Remedies in the Field of Public Procurement' (Commission Staff Working Document) SEC (2006) 557 (Annex to the 'Proposal for a Directive of the European Parliament and of the Council amending Council Directives 89/665/EEC and 92/13/EEC CEE with regard to improving the effectiveness of review procedures concerning the award of public contracts' COM (2006) 195).

48 Council Directive 92/13/EEC of 25 February 1992 coordinating the laws, regulations and administrative provisions relating to the application of Community rules on the procurement procedures of entities operating in the water, energy, transport and telecommunications sectors [1992] OJ L76/14.

49 Frederic L Kirgis, Prior Consultation in International Law (University Press of Virginia, Charlottesville 1983) 375. Cf JG Merrills, International Dispute Settlement ( $2^{\text {nd }}$ edn Grotius Publications Ltd, Cambridge 1991) 3-4, who distinguishes between consultation, notification and prior consent in international dispute settlement, the latter being 'an extremely important power'. The author recognises that when 'closer regulation is needed more complex institutional arrangements may be appropriate'.

50 EC Commission, 'Proposal for a Directive of the European Parliament and of the Council amending Council Directives 89/665/EEC and 92/13/EEC CEE with regard to improving the effectiveness of review procedures concerning the award of public contracts' COM (2006) 195 final, preambular para 20.

51 Answer by Commissioner Monti on behalf of the Commission (23 October 1997) to Written Question No 2722/97 by Jesús Cabezón Alonso to the Commission (Awarding of contracts for projects co-financed by the European Union) [1998] OJ C134/18.
} 
and it is in this context that the Commission's attempt to decentralise supervision by strengthening citizens' remedies against infringements should be seen.

\section{Safeguard and emergency measures}

Though the Court generally appraises Member State measures and their compatibility with Community law, ${ }^{52}$ there are exceptions and some of these relate to safeguard measures taken unilaterally by Member States. There is no all-encompassing design for these safeguard-clauses, however the standard type comprises two correlated provisions. One authorises the Member State to take interim measures in derogation from a given harmonised requirement conditional on immediate notification of the Commission. The other allows the Commission to apply the measures at the Community level by means of a committee procedure. At times a Member State will be required to withdraw a product from the market. ${ }^{53}$ The special procedures, effective over a limited time period, are stipulated directly in Community primary law. Maintenance of public order and the safeguarding of internal security, the ECJ stresses, fall within the Member States' exclusive competences which affects the margin of discretion enjoyed by the Member States. ${ }^{54}$ To prevent Member States from unilaterally introducing protectionist measures disguised as safeguard measures, the Commission has attained special powers of supervision. This right to monitor provisional measures includes powers to require modifications or changes of the measures. ${ }^{55}$ Similar instruments are established concerning derogations from Common Market harmonisation measures ${ }^{56}$ and national security measures. ${ }^{57}$

According to Article $152 \mathrm{EC}$, a high level of human health protection shall be ensured in the implementation of all Community policies and activities. The Council shall contribute to that objective through adopting

\footnotetext{
52 Article 220 EC.

53 Opinion of Advocate General Jacobs in Case C-359/92 Germany $v$ Council [1994] ECR I-3681, with reference to Claus-Dieter Ehlermann, 'The Internal Market following the Single European Act' (1987) 24 CML Rev 361, 398-399. See eg Article 9 of Council Directive 92/59/EEC of 29 June 1992 on general product safety. The provision enables the Commission to adopt a decision requiring Member States to take measures whereby the placing of a specific consumer product on the market is restricted or that product is withdrawn from the market.

54 Case C-265/95 Commission v France [1997] ECR I-6959 para 33.

55 European Commission, Directorate General Internal Market (Agnete Philipson), 'Guide to the Concept and Practical Application of Articles 28-30 EC' (January 2001) 23 <http:// ec.europa.eu/enterprise/regulation/goods/docs/art2830/guideart2830_en.pdf> accessed 21 September 2007.

56 Articles 95(4) - 95(9) EC.

57 Articles 296, 297 and 298 EC.
} 
measures in the veterinary and phytosanitary fields which have as their direct objective the protection of public health. There may be overriding considerations that call for rapid action against non-compliance in addition to the general interest in ensuring compliance. More recently, the food security rules have been strengthened substantially in favour of the Commission. In the motivation supplementing a 2002 legislative proposal, the Commission argued that the emergency measures it had tabled and which were eventually adopted by the Council and EP, would 'allow effective action to be taken and avoid artificial disparities in the treatment of food representing a serious risk to human health'. ${ }^{58}$ The Commission maintained that severe food crises had revealed a need for crisis management procedures. Growing concern resulted from a number of animal feed and food scares which took place in the 1990s, in particular, the Belgian crisis in 1999 concerning animal products contaminated with dioxin and polychlorinated biphenyls (PCBs). Under the 2002 regulation, the Commission, acting on its own-initiative or at the demand of a Member State, can choose among a range of measures of varying intensity in accordance with the situation's seriousness. The most rigorous action is suspension of the placing on the market or use of the food in question. ${ }^{59}$ The measure is no doubt of an intrusive nature because the Member State is without influence on the Commission's decision. However, the powers conferred upon the Commission are carefully counterbalanced by a supplementary clause which prescribes that the instrument chosen must be confirmed, amended, revoked or extended within the framework of a regulatory committee. ${ }^{60}$

The Commission readily admits that the measures are interchangeable with Article 226 EC. Thus, in a later proposal for a regulation on Community safeguard measures concerning feed and food controls, the Commission reasons that the Treaty infraction procedure

offers a tool for the Commission to proceed against Member States that fail to implement Community law. Although this procedure is a powerful instrument, the time constraints imposed render it imprac-

\footnotetext{
58 EC Commission, 'Proposal for a Regulation of the European Parliament and of the Council laying down the general principles and requirements of food law, establishing the European Food Authority, and laying down procedures in matters of food' COM (2000) 716 preambular para 56.

59 Regulation No 178/2002 of the European Parliament and of the Council of 28 January 2002 laying down the general principles and requirements of food law, establishing the European Food Safety Authority and laying down procedures in matters of food safety [2002] OJ L31/1 art 53. The Regulation has a legal basis in Articles 37, 95, 133 and 152(4)(b) EC.

60 See Article 5 of Council Decision 1999/468/EC of 28 June 1999 laying down the procedures for the exercise of implementing powers conferred on the Commission [1999] OJ L184/23.
} 
tical where a failure to implement Community law requires prompt action to safeguard feed and food safety. ${ }^{61}$ (emphasis added)

In the particular case of dioxin contamination, the award of executive powers to the Commission has had considerable merits in terms of scaling-down the Commission's action as Guardian of the Treaty under Article 226 EC ensuring the free movement of trade. Thus, in 1999 alone, the dioxin emergency triggered 100 cases under Article 226 EC. ${ }^{62}$ Proceedings were opened against Belgium, which was held responsible for failing, for months, to inform the Commission of contamination. ${ }^{63} \mathrm{Howev}$ er the majority of cases concerned other Member States, which imposed unlawful trade restrictions against Belgium in response to its apparent non-compliance.

\section{Correction/conditionality}

In addition to the Council's own powers and those it may consequently delegate according to Articles 202 and $211 \mathrm{EC}$, there are also executive powers that the EC Treaty attributes to the Commission. ${ }^{64}$ One such power concerns the EC budget. The question of delegation is not relevant in those situations. According to Article 274 EC, the Commission shall implement the budget

on its own responsibility and within the limits of the appropriations, having regard to the principles of sound financial management. Member States shall cooperate with the Commission to ensure that the appropriations are used in accordance with the principles of sound financial management.

The Council is entitled to make adoption of decisions of individual application and with financial effects subject to comitology. This right stems from Article 202 EC and, the Court asserts, does not infringe the

61 EC Commission, 'Proposal for a Regulation of the European Parliament and of the Council on official feed and food controls' COM (2003) 52 preambular para 56.

62 EC Commission, ' $17^{\text {th }}$ Annual Report on Monitoring the Application of Community Law (1999)’ [2001] OJ C30/1.

63 The notification obligation is stipulated in Council Directive 89/662/EEC of 11 December 1989 concerning veterinary checks in intra-Community trade with a view to the completion of the internal market [1989] OJ L395/13 and Council Directive 90/425/EEC of 26 June 1990 concerning veterinary and zootechnical checks applicable in intra-Community trade in certain live animals and products with a view to the completion of the internal market [1990] OJ L224/29.

64 Sabine Schlacke, 'Centralization and Europeanization of Administrative Implementation: Product Safety Legislation' in Mads Andenas and Alexander Türk (eds), Delegated Legislation and the Role of Committees in the EC (Kluwer Law International, The Hague 2000), generally and p 304 especially. 
Commission's power under Article $274 \mathrm{EC}$ to implement the budget on its own responsibility. ${ }^{65}$

According to Article 158 EC, the Community shall 'develop and pursue its actions leading to the strengthening of its economic and social cohesion' with a view 'to promot[ing] its overall harmonious development'. The Community's chief aim is to reduce 'disparities between the levels of development of the various regions and the backwardness of the least favoured regions or islands, including rural areas'. ${ }^{66}$ In the period 2000-06, the regional policies were allocated some 213 billion euros. 195 billion euros were assigned under the Structural Funds and 18 billion euros under the Cohesion Fund. Amounting to 35\% of the Community budget, regional funds make up the second-largest item on the Community budget. ${ }^{67}$

The autonomous powers of the Commission have been used to forge the Commission's role in EU regional policy. Bausili, thus notes that the Commission, particularly owing to its institutional autonomy, has been the driving force behind the current system where funding relies on Community criteria. ${ }^{68}$ The development has resulted in 'material expansion of competences, or to the development of new policy directions', ${ }^{69}$ which effectively covers the fact that the Rome Treaty did not foresee the inception of structural funds. In its administrative function managing EC resources and in particular the Community structural funds, ${ }^{70}$ the Commission possesses implementing powers that bear some resemblance to actual enforcement powers. Significantly, the processual arrangements include compliance assessments and the ensuing appraisals entail genuine consequences such as the loss of privileges. In his treatment of sanctions imposed by the Community on national authorities, Hžkkerup includes such arrangements because 'the Community has chosen to use charges on Member States and deposits for payments as a substitute for true sanctions'. ${ }^{71}$ The ECJ has recognised that CAP Council can establish

65 Case C-16/88 Commission v Council [1989] ECR 3457 para 18.

66 Article 158E EC.

67 See SCADPlus website, glossary entry for Structural Funds and Cohesion Fund <http:// europa.eu.int/scadplus/glossary/structural_cohesion_fund_en.htm> accessed 21 September 2007.

68 AV Bausili, 'Rethinking the Methods of Dividing and Exercising Powers in the EU: Reforming Subsidiarity and National Parliaments' (2002) Jean Monnet WP 9.

69 Ibid 3.

70 The European Regional Development Fund (Articles 177-181 EC), the European Social Fund (Articles 146-148 and 158-162 EC), the Financial Instrument for Fisheries Guidance and the Guidance Section of the European Agricultural Guidance and Guarantee Fund (EAGGF) (Article 37 EC) and European Regional Development Fund (Article 161 EC, Articles 163-173 EC).

71 Nick Hžkkerup, Controls and Sanctions in the EU Law (DJOEF Publishing, Copenhagen 2001). 
penalties to be imposed on individuals by the national authorities under Article 34(3) EC. Exclusions and the surcharges challenged may go beyond the mere refund of a benefit improperly paid. The mechanism is not a mere correction tool, but has an additional enforcement purpose. ${ }^{72}$ It is different vis-à-vis Member States. Correction may effectively appear interchangeable with the general Community infringement procedure from the states' viewpoint. As an illustration, Greece maintained that a 'correction may be regarded as a penalty' in its interventions in C-332/01. ${ }^{73}$ However, whereas penalties serve the purpose of ensuring compliance in line with the literal meaning of the word, namely to punish or to deter unlawful conduct with a view to bringing about compliance, conditionality is different in its purpose and method. It is a substantive and formal management principle and its modus operandi for clearing accounts 'serve to determine that the financial burdens [...] are correctly apportioned between the Member States and the Community'. ${ }^{74}$ The mechanism is foreseen to remedy unlawful expenditure and the correction is typically proportional to the scale of the infringement, ie the unlawful reception of aid.

Some guidance on the effective difference between penalties and administrative measures can be seen in Council Regulation 2988/95 on the protection of the European Communities' financial interests. In this regulation, the administrative measures are aimed at the "withdrawal of ... wrongly obtained advantage' either by (re)payment of the received amount or total or partial loss of prepaid security. There is a correlation between the unlawfully obtained amount and the size of the administrative fine. More exactly, the method of calculation entails that there is no sanctioning effect in the corrective measure.

The relationship between the Commission's actions as an executive branch of government managing structural funds and in its function as Guardian of the Treaty has been clarified by the ECJ. De jure, the procedures are not related and action undertaken under one is without relevance for the other. In C-325/94 P An Taisce $v$ Commission, An Taisce, The National Trust for Ireland, and the World Wide Fund for Nature UK, brought a case against the Commission seeking, first, annulment of its decision not to suspend or withdraw the allocation of Community structural funds for financing an interpretative centre for tourists in Mullaghmore, Ireland and, secondly, not to initiate proceedings under Article 226

72 Case C-240/90 Germany $v$ Commission [1992] ECR I-5383 para 29.

73 Case C-332/01 Greece v Commission [2004] ECR I-7699. See also Case C-247/98 Greece $v$ Commission [2001] ECR I-1 paras 13 and 14.

74 Case C-247/98 Hellenic Republic v Commission [2001] ECR I-1 para 13. 
EC for failure to live up to Community environmental standards. ${ }^{75}$ The applicants claimed that the Court of First Instance should annul both decisions. However, it is at the Commission's discretion whether or not to initiate infringement proceedings under Article 226 EC. The remaining question was whether such a decision implicitly meant that the Commission also decided, at that time, not to make use of the possibility given it by Regulation No $4253 / 88$ to suspend or reduce the use by the Irish authorities of Community funds. The Court of First Instance and, upon review, the ECJ rejected this interpretation. ${ }^{76}$ The Court ruled that the "two procedures are independent of each other, serve different aims and are subject to different rules' 77 as justification for why a decision in the administrative phase of Article $226 \mathrm{EC}$ is without prejudice to structural funds. The Commission has subsequently decided that although politically and legally independent of each other 'there must be some degree of consistency between the two [procedures] $\cdot{ }^{78}$ In practice this has come to mean that the Commission as a rule suspends grant payments when it issues a letter of formal notice. When a reasoned opinion is issued, the Commission will initiate a process to reduce or withdraw funding. ${ }^{79}$ The Commission nonetheless emphasises that the jurisprudence does not imply that the procedures are mutually exclusive and therefore it retains full discretion under these procedures. ${ }^{80}$ Decisions concerning structural funding are binding and the Member States have appeal to the ECJ under Article 230 EC.

The political nature of the Commission's function under EC enforcement procedure is reflected in the Commission decision-making process. Thus, although the different Directorate Generals' (DG) work independently in the administrative phases of Article $226 \mathrm{EC}$, it is the Commission as a college that decides on recourse to the ECJ. ${ }^{81}$ In matters of supervision of revenue and expenditure, the decision-making power can

75 Council Directive 85/337/EEC of 27 June 1985 on the assessment of the effects of certain public and private projects on the environment [1985] OJ L175/40 and Council Directive 80/68/EEC of 17 December 1979 on the protection of groundwater against pollution caused by certain dangerous substances [1980] OJ L20/43.

76 Case T-461/93 An Taisce $v$ Commission [1994] II-733 para 38 and Case C-325/94 P An Taisce $v$ Commission [1996] ECR I-3727 para 37.

77 Case C-325/94 P (n 76) summary.

78 EC Commission, ' $16^{\text {th }}$ Annual Report on Monitoring the Application of Community Law (1998)’ [1999] OJ C354/1.

79 EC Commission, '17 $7^{\text {th }}$ Annual Report' (n 62).

80 EC Commission, ' $15^{\text {th }}$ Annual Report on Monitoring the Application of Community Law (1997)’ [1998] OJ C250.

81 Case C-191/95 Commission v Germany [1998] ECR I-5449 para 34. 
be delegated to the relevant DG. ${ }^{82}$ It thus takes the form of an administrative decision and the political dimension is as a result significantly down-played. This is in part because the Commission is obliged under Article 280, para 1 to retrieve unlawful payments, 'whether by error, irregularity or deliberate fraud'. ${ }^{83}$ Surely it makes a difference that conditionality for subsidies for the most is based on premises that are fairly concrete although the Commission may enjoy some discretion in determining whether they have been met. Such executive decision making is fundamentally different from the semi-political choices made by the Commission under the infringement procedure. The College, naturally, retains collective responsibility. ${ }^{84}$ However, the concrete responsibility for implementation varies, and the 'authorising officer delegate' will often be the Director Generals or Heads of Service. ${ }^{85}$

The political trait of the general Community infringement procedure, as is apparent from the margin of discretion attributed to the Commission, does not necessarily apply to the legal framework of the structural funds. Instead, the Commission may be obliged to undertake financial correction where the conditions for funding have not been observed. ${ }^{86}$ Whether a correction will take place may rest on a culpability criterion whereas the general infringement procedure is of a neutral nature even in relation to the imposition of sanctions under Article 228 EC. ${ }^{87}$ Where there is a margin of discretion, the Commission will make an assessment of the region affected and ensure that poor regions are not disproportionately harmed and that any development process will not be compromised unnecessarily. ${ }^{88}$

To recap, the legislator may make entitlement to resources conditional upon compliance with Community law. Moreover, implementing the system is within the Commission's executive and not its supervisory

\footnotetext{
82 Commission Decision 74/55/EEC of 22 January 1974 conferring powers to carry out measures of control in Member States in respect of Community revenue and expenditure [1974] OJ L34/28.

83 EC Commission, 'Implementation of the European Union's Budget' MEMO (2005) 421, 14 November 2005.

84 See Rules of Procedure of the European Commission [2000] OJ L308/26 art 13 and 14 .

85 See EC Commission, 'Implementation of the European Union's Budget' (n 83).

86 Case C-332/01 Greece $v$ Commission [2004] ECR I-7699 para 63.

87 See eg Regulation No 1655/1999 laying down general rules for the granting of Community aid in the field of trans-European networks [1999] OJ L197/1: 'Except where the Member States and/or the implementing authority provide proof that they were not responsible for the irregularity, the Member State shall be liable in the alternative for reimbursement of any sums unduly paid.' In comparison, the ECJ has consistently held that internal circumstances cannot constitute a mitigating effect when ruling on compliance under the general infringement procedure.

88 EC Commission, ' $16^{\text {th }}$ Annual Report' (n 78).
} 